\title{
Cloning and Sequencing of the gerD Gene of Bacillus subtilis
}

\author{
By J. R. YON, $\uparrow$ R. L. SAMMONS* AND D. A. SMITH \\ School of Biological Sciences, University of Birmingham, Birmingham B15 2TT, UK
}

(Received 2 August 1989; accepted 18 September 1989)

\begin{abstract}
A $\mathrm{Tn} 917$ insertion in the same region of the chromosome as ger $D$ gave rise to a mutant (ger-97) with a germination phenotype similar to that of two ger $D$ mutants which germinate abnormally in a range of germinants. The insertion and two ger $D$ mutations were cotransformed with ribosomal protein genes $r p o B, r p s E$ and $r p s I$. DNA cloned from one side of the insertion carried the $16 \mathrm{~S}$ end of the ribosomal RNA operon $r r n I$. These data were consistent with the order $r p o B-$ rpsE-rpsI-gerD/ger-97::Tn917-rrnI. Insertion into the wild-type chromosome of a plasmid carrying DNA adjacent to the insertion permitted the recovery of a $1.8 \mathrm{~kb}$ fragment of DNA which complemented ger-97: : Tn 917 and the ger $D$ mutations. The DNA nucleotide sequence of the region of this fragment at which $\mathrm{Tn} 917$ had inserted revealed a 555 bp open reading frame, preceded by a ribosome-binding site and potential $\sigma^{\mathrm{E}}$ and $\sigma^{\mathrm{A}}$ promoter regions and encoding a predicted polypeptide of $21117 \mathrm{Da}$. This polypeptide was largely hydrophilic but contained a hydrophobic region at the $\mathrm{N}$-terminus resembling a signal peptide.
\end{abstract}

\section{INTRODUCTION}

Spores of Bacillus subtilis germinate in response to L-alanine (Ala) or a mixture of Lasparagine, glucose, fructose and $\mathrm{KCl}$ (AGFK). Mutants have been isolated which germinate abnormally in response to either or both of these germinants (Moir et al., 1979, 1985; Piggot et al., 1981). The mutations giving rise to germination abnormalities have been mapped in thirteen chromosomal locations (ger $A-M$ ) and so far ger $A, C, E$ and $M$ have been cloned (Moir, 1983; Yazdi, 1989; James \& Mandelstam, 1985; Hasnain et al., 1985; Sammons et al., 1987).

The products of ger genes and their roles in germination are largely unknown, although the gerG mutation is associated with loss of phosphoglycerate kinase (Prasad et al., 1972). gerE may play a regulatory role and be responsible for the appearance of several spore components including protease E (Cutting \& Mandelstam, 1986), which is absent in the gerE mutant (Jenkinson \& Lord, 1983). The gene product predicted from the ger $E$ DNA sequence appears to have the potential to bind the DNA (Holland et al., 1987). It is likely that the three open reading frames identified in the ger $A$ region encode components of the L-alanine receptor (Zuberi et al., 1985), whilst ger $K$ may be concerned with binding of glucose (Irie et al., 1982) and gerD with that of fructose (Irie et al., 1985). gerJ may be involved in the regulation of synthesis of components of the spore cortex (Warburg et al., 1986).

In this paper we describe the identification of a $\operatorname{Tn} 917$ insertion in the ger $D$ region of the chromosome between rpsI and $r r n I$ which gave rise to a mutant with a phenotype like that of

\footnotetext{
† Present address: Imperial Cancer Research Fund, Lincolns Inn Fields, London WC2A 3PX, UK.

$\ddagger$ Present address: Department of Anatomy, University of Birmingham, Birmingham B15 2TJ, UK.
}

Abbreviations: Ala, L-alanine; AGFK, asparagine/glucose/fructose/ $\mathrm{KCl}$; ORF, open reading frame.

The nucleotide sequence data reported in this paper have been submitted to GenBank and have been assigned the accession number M27259. 
previously isolated ger $D$ mutants. This insertion has permitted the cloning of DNA which complements the insertion and gerD mutations. The region of DNA in which the insertion occurred has been sequenced and the ger $D$ open reading frame identified.

\section{METHODS}

Bacteria, plasmids and phages. Strains of Bacillus subtilis 168 and Escherichia coli $\mathrm{K} 12$, plasmids and phages are listed in Table 1.

Media. (a) B. subtilis. Nutrient media were Difco Penassay Broth (PAB), Difco Nutrient Agar (NA) and potato/glucose/yeast extract agar (PGA; Dring \& Gould, 1971). Spores were prepared on NA or PGA or in CCY medium (Wilkinson et al., 1977) as described by Moir et al. (1979). Chloramphenicol $\left(5 \mu \mathrm{g} \mathrm{ml}^{-1}\right)$, rifampicin $(10 \mu \mathrm{g}$ $\left.\mathrm{ml}^{-1}\right)$, spectinomycin dihydrochloride $\left(200 \mu \mathrm{g} \mathrm{ml}^{-1}\right)$, kasugamycin hemisulphate $\left(4 \mathrm{mg} \mathrm{ml}^{-1}\right)$ and erythromycin $\left(1 \mu \mathrm{g} \mathrm{ml}^{-1}\right)$ plus lincomycin $\left(25 \mu \mathrm{g} \mathrm{ml}^{-1}\right)$ were added to NA to select for $\mathrm{Cam}^{\mathrm{R}}, \mathrm{Rif}^{\mathrm{R}}, \mathrm{Spc}^{\mathrm{R}}, \mathrm{Ksg}^{\mathrm{R}}$ and MLS phenotypes respectively. (b) E. coli. Strains were cultured in L-broth and on L-agar (Miller, 1972) plus kanamycin $\left(50 \mu \mathrm{g} \mathrm{ml}^{-1}\right)$ or ampicillin $\left(100 \mu \mathrm{g} \mathrm{ml}^{-1}\right)$ to select for $\mathrm{Kan}^{\mathrm{R}}$ and $\mathrm{Amp}^{\mathrm{R}}$ colonies respectively.

Genetical methods. Transformation of E. coli and B. subtilis was done as described by Sammons et al. (1987), using $0 \cdot 2 \mu \mathrm{g} \mathrm{DNA} \mathrm{ml}{ }^{-1}$ in the case of $B$. subtilis transformation. To select for $\mathrm{Rif}^{\mathrm{R}}$ or $\mathrm{Spc}^{\mathrm{R}}$ transformants, after the 90 min incubation of competent cells with DNA, an equal volume of L-broth was added and incubation continued for a further $3 \mathrm{~h}$ to allow time for expression of mutant genes before plating on selective media.

Spore germination. This was monitored by following loss of optical density at $580 \mathrm{~nm}\left(\mathrm{OD}_{580}\right)$ of spore suspensions after addition of germinants. Prior to germination, spores were heat-activated at $70^{\circ} \mathrm{C}$ for $30 \mathrm{~min}$ as described by Sammons et al. (1981). The spore germination phenotype of bacterial colonies was determined by the tetrazolium overlay method (Trowsdale \& Smith, 1975), in which $\mathrm{Ger}^{+}$colonies are red (tzm-red) and $\mathrm{Ger}^{-}$ colonies white (tzm-white).

Gene cloning techniques. Extraction of chromosomal or plasmid DNA, DNA restriction and ligation, gel electrophoresis, Southern blotting and hybridization were all carried out as previously described (Sammons et al., 1987). DNA fragments were size-fractionated by electrophoresis using low-gelling-temperature agarose, followed by electroelution.

DNA sequencing. To determine the sequence of the $1.86 \mathrm{~kb}$ Pst I fragment from $\lambda 2 \mathrm{H}$ it was cloned in both orientations into the PstI site of M13mp19 (Yanisch-Perron et al., 1985). Digestion with SaII and KpnI allowed progressive deletions to be made into the insert with exonuclease III as described by Henikoff (1984). Following S1 nuclease treatment the ends were filled in using Klenow polymerase, ligated and the DNA used to transfect $E$. coli strain JM101. This gave a series of clones which were sequenced by the method of Sanger $e$ t al. (1977) as described in the Bethesda Research Laboratory manual 'M13 Cloning and Dideoxy Sequencing' (1980). Buffer gradient gels were poured as described by Biggin et al. (1983).

Phage $\lambda$ techniques. Preparation of plating cells, phage propagation and assay, purification and reisolation of phage from single plaques were as described by Murray et al. (1973). Large-scale preparation of $\lambda$ DNA was done as described by Sammons \& Anagnostopoulos (1982). A library of $B$. subtilis DNA was constructed in $\lambda$ EMBL3 as follows. Chromosomal DNA from strain 1604 was digested to completion with Bg/II and ligated to $\lambda$ EMBL3 DNA cleaved with $B a m H I$ and $E c o$ RI. The recombinant DNA was packaged using a packaging extract prepared as described by Maniatis et al. (1982). To identify clones carrying DNA from the ger-97 region, approximately 2000 plaques were screened by hybridization to the ${ }^{32}$ P-labelled 2.1 kb EcoRI-PstI fragment from pBMD1 (Fig. 3) using the method of Benton \& Davis (1977). Nine plaques which gave positive signals were rescreened at low density and DNA prepared from phage taken from single positive plaques was analysed by restriction enzyme digestion.

\section{RESULTS}

\section{Isolation of the ger-97: :Tn917 mutant}

Transposon Tn917 mutagenesis of strain PY143 was carried out using the method of Youngman et al. (1983) as previously described (Sammons et al., 1987). A mutant was isolated which was MLSR and white by the tetrazolium overlay test (strain 5189). To study the effect of the transposon insertion (ger-97::Tn917) in the same genetical background as other strains in our laboratory, it was transformed into strain 1604 by selection for MLS ${ }^{\mathrm{R}}$. All the transformants were tzm-white and one representative, strain 5215, whose $\mathrm{Ger}^{-}$phenotype was identical to that of the original mutant, was chosen for further study. 
Table 1. Bacterial strains, plasmids and phages

Bacterial strains

\section{B. subtilis}

PY143

1604

CA302

CA310

4738

4928

4930

5183

5189

5207

5208

5213

5215

5224

5225

5226

5227

5277

E. coli

NEM259

TBI

JM101

Plasmids

pTV1

pTV20

pTV21 22

pSGMU2

pMK4

pBMD1

pBMD2

pBMD7

pBMD10

pBMD11

pBMD12

pBMD13

pBMD14

pBMD16

pBMD17

pBMD18

Phages

$\lambda P 13$

AEMBL3

$22 \mathrm{H}$

M13mp19
Genotype and/or phenotype
Source, reference or origin

\author{
Prototroph carrying pTV1 \\ $\operatorname{trpC2}$ (wild-type) \\ cysA14 trpC2 purA16 rpsE302 $\mathrm{Spc}^{\mathrm{R}}$ \\ cysA14 trpC2 purA16 rpoB rpsI2 $\mathrm{Rif}^{\mathrm{R}} \mathrm{Ksg}^{\mathrm{R}}$ \\ $\operatorname{trp} C 2$ ger $D 48$ \\ arg-15 leuA8 thr-5 $\mathrm{r}_{\mathrm{M}}^{-} \mathrm{m}_{\overline{\mathrm{M}}}^{-}$recE4 \\ $\arg -15$ leuA $8 \mathrm{r}_{\mathrm{M}}^{-} \mathrm{m}_{\overline{\mathrm{M}}}^{-}$ \\ trpC2 gerD25 \\ ger-97::Tn917 MLSR $^{R}$ \\ $\operatorname{trpC2}$ rpsE302 $\mathrm{Spc}^{\mathrm{R}}$ \\ $\operatorname{trpC} 2 \operatorname{rpsI} 2$ rpoB $\mathrm{Ksg}^{\mathrm{R}} \mathrm{Rif}^{\mathrm{R}}$ \\ ger $D 48$ \\ trpC2 ger-97: : Tn 917 MLS $^{\mathrm{R}}$ \\ arg-15 leuA8 $\mathrm{r}_{\overline{\mathrm{M}}}^{-} \mathrm{m}_{\overline{\mathrm{M}}}^{-}$ger-97::Tn917 MLS $^{\mathrm{R}}$ \\ leuA $8 \mathrm{r}_{\bar{M}}^{-} \mathrm{m}_{\overline{\mathrm{M}}}^{-} \operatorname{gerD} 48$ \\ arg-15 $\mathrm{r}_{\mathrm{M}}^{-} \mathrm{m}_{\overline{\mathrm{M}}}^{-}$rec E4 ger-97: :Tn917 MLS \\ trpC2 $\mathrm{r}_{\mathrm{M}}^{-} \mathrm{m}_{\mathrm{M}}^{-}$rec E4 gerD48 \\ trpC2 ger-97::Tn917::pTV21 $22 \mathrm{Cm}^{\mathrm{R}}$ \\ supE supF hsdR hsdM+ met trpR \\ ara $\triangle($ lac-proAB) rpsL $\phi 80$ lacZ M15 \\ hsdR hsdM+ \\ supE thi $\triangle$ (lac-proAB) $\mathrm{F}^{\prime}$ traD36 \\ ProAB- lacI lacZ M15
}

Description/derivation

$\mathrm{Cm}^{\mathrm{R}} \mathrm{MLS}^{\mathrm{R}}$; carries $\operatorname{Tn} 917$

$\mathrm{Cm}^{\mathrm{R}} \mathrm{Ap}^{\mathrm{R}} \mathrm{MLS}^{\mathrm{R}}$; Tn917 DNA

$\mathrm{Cm}^{\mathrm{R}} \mathrm{Ap}^{\mathrm{R}}$; Tn917 DNA

$\mathrm{Cm}^{\mathrm{R}} \mathrm{Ap}^{\mathrm{R}} ; \boldsymbol{B}$. subtilis integrative vector

with cloning site from $\mathrm{pUC13}$

E. coli/B. subtilis shuttle vector

Derived from pTV20 in 5215

ger97 flanking DNA cloned in pSGMU2

Derived from pTV21 $\Delta 2$ in 5215

ger97 region cloned in pSGMU2

$1.8 \mathrm{~kb}$ Pst I ger-97 fragment cloned in pMK4

$1.8 \mathrm{~kb}$ Pst I ger-97 fragment cloned in pSGMU2

Description/derivation

Carries part of $r r n G$

$\lambda$ replacement vector

Recombinant phage carrying rRNA

sequences
Youngman et al. (1983)

Lafferty \& Moir (1977)

Dabbs (1983)

E. R. Dabbs (Max-Planck Institute, Berlin)

EMS mutagenesis of 1604;

Warburg et al. (1985)

BGSC (strain 1A423)

BGSC (strain 1A253)

NTG mutagenesis of 1604; Roberts (1983)

Tn917 mutagenesis of PY143 (this study)

rpsE302 transformed from CA302 into 1604

$r p s I 2$ and $r p o B$ transformed from

CA310 into 1604

$4738 \times$ PY79

This study

$4930 \times 5215$ selecting MLS $^{R}$

$4930 \times 5213$ (congression, selecting $\mathrm{Arg}^{+}$)

$5224 \times 4928$ (congression, selecting $\left.\mathrm{Leu}^{+}\right)^{*}$

$5225 \times 4928$ (congression, selecting $\mathrm{Leu}^{+}$)

$5215 \times$ p TV2 $1 \Delta 2$ selecting $\mathrm{Cm}^{\mathrm{R}}$

J. Guest (Sheffield University, UK)

Bethesda Research Laboratories

Messing (1983)

Origin or reference

Youngman et al. (1983)

Youngman et al. (1984)

Youngman et al. (1984)

Fort \& Errington (1985)

Sullivan et al. (1984)

This study

This study

This study

This study

This study

This study

Origin or reference

Bott et al. (1984)

Frischauf et al. (1983)

This study

Yanisch-Perron et al. (1985)

Abbreviations. Antibiotic resistances: Spc ${ }^{\mathbf{R}}$, specinomycin, Rif ${ }^{\mathbf{R}}$, rifampicin; Ksg ${ }^{\mathbf{R}}$, kasugamycin; $\mathbf{M L S}^{\mathrm{R}}$, macrolide lincosamide and streptogramin $\mathrm{B} ; \mathrm{Ap}^{\mathrm{R}}$, ampicillin; $\mathrm{Cm}^{\mathrm{R}}$, chloramphenicol. EMS, ethylmethane sulphonate; NTG, nitrosoguanidine. BGSC, Bacillus Genetic Stock Center.

* The Leu+ allele was supplied by 1604 DNA also present in the transformation mixture. 

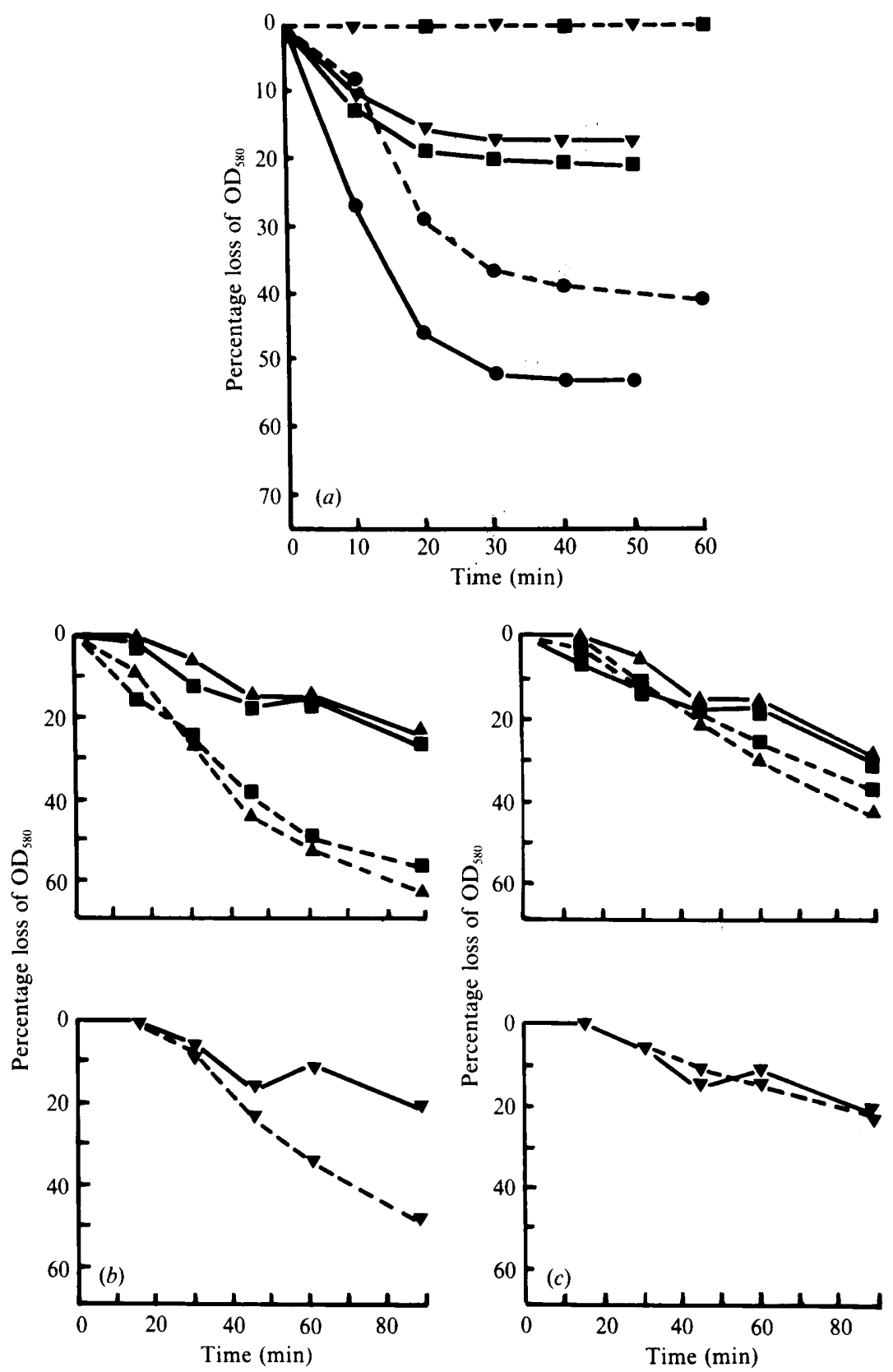

Fig. 1. Comparison of spore germination phenotypes of gerD25, gerD48 and ger-97:: Tn 917 mutants. (representative experiments showing loss of $\mathrm{OD}_{580}$ ). (a) In Ala (solid lines) and AGFK (broken lines). (b) In Ala; spores prepared on PGA (solid lines) and in CCY medium (broken lines). (c) In Ala (solid lines) and $\mathrm{Ala}+\mathrm{KCl}$ (broken lines). $\bullet$, Wild-type, strain 1604; $\boldsymbol{\square}$, gerD25 mutant, strain $5183 ; \mathbf{\Delta}$, ger $D 48$ mutant, strain $4738 ; \nabla$, ger- $97:$ : Tn 917 mutant, strain 5215 . The concentrations of germinants or adjuncts were: $\mathrm{Ala}$ and $\mathrm{KCl}, 1 \mathrm{mM}$; asparagine, glucose and fructose, $10 \mathrm{mM}$. These experiments were done at least three times; variation in loss of $\mathrm{OD}_{580}$ never exceeded $\pm 5 \%$. 


\section{Phenotype of the ger-97::Tn917 mutant}

Vegetative growth and sporulation of strain 5215 appeared to be normal. Spores were prepared on PGA plates and germination was compared with that of spores of the wild-type and previously isolated gerD mutants, strains 4738 (gerD48) and 5183 (gerD25), prepared at the same time. Germination was monitored by following loss of $\mathrm{OD}_{580}$ after the addition of Ala and AGFK to spore suspensions. The $\mathrm{OD}_{580}$ of all the mutant suspensions fell by approximately $20 \%$ in Ala in 60 min whilst that of the wild-type strain fell by approximately $50 \%$. In AGFK the $\mathrm{OD}_{580}$ of mutant spores remained unaltered whilst that of the wild-type suspension fell by approximately $40 \%$ (Fig. 1 a).

Warburg (1981) found that the sporulation medium affected the subsequent rate of germination of spores of ger $D$ mutant strains. To test this, instead of the resuspension technique used by Warburg, spores were prepared in CCY medium, as this exhaustion medium was simpler to use but produced a similar effect on germination. The rates of response of spores of the gerD 25 , ger $D 48$ and ger-97:: Tn 917 mutants all increased by a similar amount when spores were prepared in this medium (Fig. $1 b$ ).

Spores of ger $D$ mutants show an improved response to Ala as germinant when $\mathrm{K}^{+}$or other monovalent cations are also present (Warburg et al., 1985). However, the response of spores of strain 5215 to Ala was not improved by the addition of $\mathrm{KCl}$ whilst the rates of germination of suspensions of spores of strains 4738 and 5183 showed a slight increase when $\mathrm{KCl}$ was present (Fig. 1c).

These experiments suggested that the germination phenotype of the ger-97:: $\operatorname{Tn} 917$ mutant was similar to that of the ger $D$ mutants except that no improvement in the rate of germination in Ala was seen on addition of $\mathrm{KCl}$.

\section{Map location of gerD25, gerD48 and ger-97: :Tn917 mutations}

Using phage PBS1, gerD mutations were $77-80 \%$ cotransduced with cys $A$ (Moir et al., 1979), and using phage SPPl, they were $1-8 \%$ contransduced with $r p l V$, the order of markers being cys $A-r p l V$-gerD (Warburg et al., 1985). rplV is one of a group of ribosomal protein genes in this area which include rpoB, rpsE and rpsI (Dabbs, 1983; Henkin \& Chambliss, 1984; Fig. 2). Since it seemed likely that ger $D$ and the Tn917 insertion would be close to or within this cluster, gerD25, gerD48 and ger-97::Tn917 were mapped with reference to these genes.

DNA from strains 5208 ( $r p o B$ rpsI2 trpC2) and 5207 ( rpsE302 trpC2) was used to transform strains 5183, 4738 and 5215, selecting for rifampicin resistance (rpoB) or spectinomycin resistance ( $r p s E)$. It was necessary to perform the crosses with strains 5208 and 5207 as donors because these strains did not become competent by the procedure used : typically 1000 -fold fewer transformants were obtained with these strains as recipients.

The lesions in gerD48 and gerD25 appeared to be very close, as each was transformed at essentially the same frequency with $r p o B(6 \%)$ and $r p s E 302(31 \%)$ (Table 2). These results suggest that ger $D$ is further from $r p o B$ than it is from rpsE302. Taken together with published cotransformation frequencies in this region (Fig. 2), the data suggest the order cys $A-r p o B-r p s E-$ ger $D$. The finding of Warburg (1981) that ger $D$ was not cotransformed with $c y s A$ also supports this order. The crosses between strains 5208 and 4738 or 5183 were scored with gerD and rpsI2 (kasugamycin resistance) as unselected markers. In both cases the percentage of $\mathbf{R i f}^{\mathbf{R}}$ and $\mathbf{K s g}^{\mathbf{R}}$ transformants (20\% and $16 \%$ for the crosses with strains 4738 and 5183 respectively) was higher than the percentage of $\mathrm{Rif}{ }^{\mathrm{R}}$ tzm-red transformants $(6 \%$ in each case), indicating that the distance from rpsI to $r p o B$ is less than the distance from ger $D$ to $r p o B$. Since cotransformation frequencies were low and the rarest class of recombinants in the crosses with strains 4738 and 5183 different, no conclusions were drawn from these crosses about the order of these markers. However, rpsI is cotransformed at low frequency with cys $A$ (Fig. 2), suggesting that it lies between ger $D$ and cys $A$. Fig. 2 shows the most likely order of markers in this region compiled from published transformation data and the results in Table 2. It is not clear how transposon Tn917 affects the results of cotransformation experiments, as the lesion results from the insertion of $5.4 \mathrm{~kb}$ of DNA. The transposon may affect linkage frequencies differently 
Table 2. Transformation crosses with gerD and ger-97::Tn917

\begin{tabular}{|c|c|c|c|c|}
\hline Donor* & Recipient* & $\begin{array}{l}\text { Selected } \\
\text { marker }\end{array}$ & $\begin{array}{l}\text { Recombinant } \\
\text { class }\end{array}$ & No. \\
\hline $5208(\operatorname{trpC2} r p o B$ rpsI2) & $5183(\operatorname{trp} C 2$ gerD25) & $\operatorname{Rif}^{\mathbf{R}}$ & $\begin{array}{l}\text { Rif }^{R} \text { Ksg }^{\mathrm{R}} \mathrm{Ger}^{-} \\
\text {Rif }^{\mathrm{R}} \mathrm{Ksg}^{\mathrm{S}} \mathrm{Ger}^{-} \\
\text {Rif }^{\mathrm{R}} \mathrm{Ksg}^{\mathrm{R}} \mathrm{Ger}^{+} \\
\text {Rif }^{\mathrm{R}} \mathrm{Ksg}^{\mathrm{S}} \mathrm{Ger}^{+}\end{array}$ & $\begin{array}{r}16 \\
109 \\
5 \\
2\end{array}$ \\
\hline 5208 & $4738(\operatorname{trp} C 2$ gerD 48$)$ & $\operatorname{Rif}^{R}$ & $\begin{array}{l}\text { Rif }^{\mathrm{R}} \mathrm{Ksg}^{\mathrm{R}} \mathrm{Ger}^{-} \\
\text {Rif }^{\mathrm{R}} \mathrm{Ksg}^{\mathrm{S}} \mathrm{Ger}^{-} \\
\text {Rif }^{\mathrm{R}} \mathrm{Ksg}^{\mathrm{R}} \mathrm{Ger}^{+} \\
\text {Rif }^{\mathrm{R}} \mathrm{Ksg}^{\mathrm{S}} \mathrm{Ger}^{+}\end{array}$ & $\begin{array}{r}132 \\
24 \\
101 \\
2 \\
5\end{array}$ \\
\hline 5208 & $\begin{array}{l}5215(\operatorname{trp} C 2 \\
\text { ger-97::Tn917) }\end{array}$ & $\mathrm{Rif}^{\mathrm{R}}$ & $\begin{array}{l}\text { Rif }^{R} \mathrm{Ksg}^{\mathrm{R}} \mathrm{Ger}^{-} \\
\text {Rif }^{\mathrm{R}} \mathrm{Ksg}^{\mathrm{S}} \mathrm{Ger}^{-} \\
\text {Rif }^{\mathrm{R}} \mathrm{Ksg}^{\mathrm{R}} \mathrm{Ger}^{+} \\
\text {Rif }^{\mathrm{R}} \mathrm{Ksg}^{\mathrm{S}} \mathrm{Ger}^{+}\end{array}$ & $\begin{array}{r}132 \\
52 \\
190 \\
19 \\
5\end{array}$ \\
\hline 5207 (trpC2 rpsE302) & 5183 & $\mathrm{Spc}^{\mathrm{R}}$ & $\begin{array}{l}\mathrm{Spc}^{\mathrm{R}} \mathrm{Ger}^{-} \\
\mathrm{Spc}^{\mathrm{R}} \mathrm{Ger}^{+}\end{array}$ & $\begin{array}{r}264 \\
91 \\
41\end{array}$ \\
\hline 5207 & 4738 & $\mathrm{Spc}^{\mathrm{R}}$ & $\begin{array}{l}\mathrm{Spc}^{\mathrm{R}} \mathrm{Ger}^{-} \\
\mathrm{Spc}^{\mathrm{R}} \mathrm{Ger}^{+}\end{array}$ & $\begin{array}{r}132 \\
91 \\
41\end{array}$ \\
\hline 5207 & 5215 & $\mathrm{Spc}^{\mathrm{R}}$ & $\begin{array}{l}\operatorname{Spc}^{R} \operatorname{MLS}^{R}\left(\mathrm{Ger}^{-}\right) \\
\operatorname{Spc}^{R} \operatorname{MLS}^{R}\left(G e r^{+}\right)\end{array}$ & $\begin{array}{r}132 \\
110 \\
22\end{array}$ \\
\hline
\end{tabular}

${ }^{*} r p o B$ confers Rif ${ }^{\mathrm{R}}, r p s I 2 \mathrm{Ksg}^{\mathrm{R}}, r p s E 302 \mathrm{Spc}^{\mathrm{R}}$ and $\mathrm{Tn} 917 \mathrm{MLS}^{\mathrm{R}}$.

depending whether it is present in the donor or recipient strain. The results in Table 2 imply that ger-97:: $\mathrm{Tn} 917$ is further from $r p o B$ than from rpsE (cotransformation frequencies of ger-97:: Tn 917 with these markers of $8 \%$ and $17 \%$ respectively), at or near the gerD locus (Fig. 2).

\section{Cloning DNA adjacent to ger-97::Tn917}

Since the mapping data suggested that ger-97:: $\operatorname{Tn} 917$ was in the same region of the chromosome as gerD, efforts were made to clone an intact copy of the region in which this insertion had occurred, to test whether this DNA could repair gerD mutations. Plasmids pTV20 and pTV21 $\Delta 2$ were used to clone DNA from either side of ger-97::Tn917. They were linearized and used to transform strain 5215 to chloramphenicol resistance as described by Youngman et $a l$. (1984). This resulted in the introduction of $p B R 322$ replication functions and $A p^{R}$ and $C^{R}$ markers into the transposon insertion by a double crossover recombination event. Chromosomal DNA was prepared from a single transformant from each cross, digested to completion with EcoRI, which cuts once between the $\mathrm{Ap}^{\mathrm{R}}$ and $\mathrm{Cm}^{\mathrm{R}}$ markers, ligated and used to transform $E$. coli strain NEM259 to ampicillin resistance. From chromosomal DNA carrying pTV20 two plasmids (pBMD1 and pBMD2, Fig. 3) were obtained. When pBMD1 and pBMD2 were digested with EcoRI they each yielded an identical $9.0 \mathrm{~kb}$ fragment containing some pTV20 DNA and, additionally, different EcoRI fragments in each case (not shown in Fig. 3). Since in the preparation of these plasmids the chromosomal DNA had been digested to completion with $E c o$ RI it is unlikely that the additional fragments in either case represented contiguous chromosomal DNA. No plasmids were obtained which consisted only of the $9.0 \mathrm{~kb}$ fragment. 

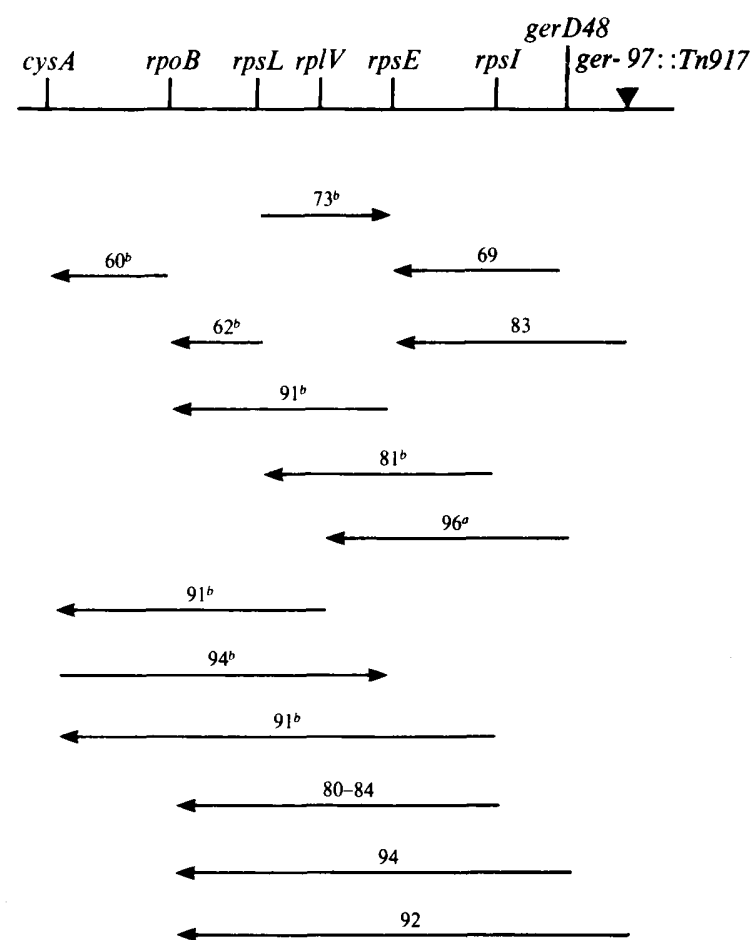

Fig. 2. Order of markers in the ger $D$ region based on transformation data. The numbers above the arrows are (100 - percentage cotransformation). Compiled from the data in Table 2 and (a) Warburg (1981) and (b) Dabbs (1983) and Henkin \& Chambliss (1984). $\nabla$, indicates the site of Tn917 insertion.
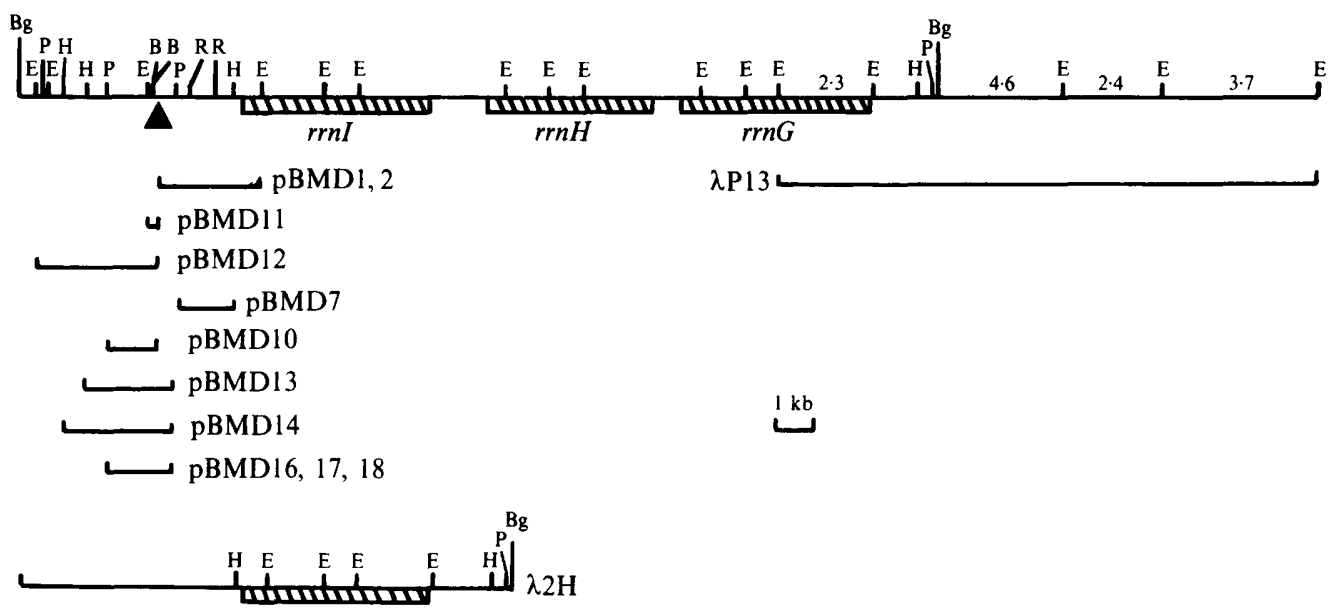

Fig. 3. Partial restriction map of the gerD-rrnI-rrnH-rrnG region and cloned DNA. $\triangle$, indicates the site of Tn 917 insertion. The hatched boxes represent rrn operons (redrawn from Jarvis et al., 1988). Bg, BgIII; E, EcoRI; P, PstI; H, HindIII; B, BamHI; R, EcoRV. Only the EcoRI sites on the rrn operons and the sizes of EcoRI fragments (kb) of $\lambda P 13$ are shown.

The restriction map of pTV20 (Youngman et al., 1984) indicates that approximately $6.4 \mathrm{~kb}$ of the plasmid recovered will contain sequences from pTV 20 which carry replication functions and the $\mathrm{Ap}^{\mathrm{R}}$ gene. The $9.0 \mathrm{~kb}$ fragment therefore contains about $2.6 \mathrm{~kb}$ of $B$. subtilis DNA adjacent to the site of the Tn917 insertion (Fig. 3). 
pBMD1 1 (Fig. 3) was prepared from chromosomal DNA carrying pTV21 $\Delta 2$ integrated into the ger-97:: Tn 917 insertion, and consists of a single $4.5 \mathrm{~kb}$ EcoRI fragment. Approximately $4.3 \mathrm{~kb}$ of this is likely to be derived from pTV21 $\Delta 2$ (Youngman et al., 1984) suggesting that the remaining $0.2 \mathrm{~kb}$ is $B$. subtilis chromosomal DNA. By combining the data from the pBMD1, pBMD2 and pBMD1 1 clones it was estimated that $\operatorname{Tn} 917$ has inserted $0.2 \mathrm{~kb}$ from one end of a $2.8 \mathrm{~kb} E c o \mathrm{RI}$ fragment (later more accurately estimated to be $2.9 \mathrm{~kb}$ ). This was confirmed by hybridization of pBMDI1 DNA to a $2.9 \mathrm{~kb}$ EcoRI chromosomal fragment from the wild-type (data not shown).

A further plasmid, pBMD12, was isolated after partial EcoRI digestion of chromosomal DNA from the strain carrying pTV21 $\Delta 2$ integrated into ger-97::Tn917. This had the $4.5 \mathrm{~kb}$ EcoRI fragment of pBMD11 plus additional fragments of 2.6 and $0.3 \mathrm{~kb}$ (Fig. 3). The $2.6 \mathrm{~kb}$ EcoRI fragment of pBMD12 hybridized to a chromosomal EcoRI fragment of this size, to Pst fragments of 1.8 and $1.6 \mathrm{~kb}$, and to HindIII fragments of $3.7 \mathrm{~kb}$ (as did pBMD11) and $0.5 \mathrm{~kb}$ (data not shown). This confirmed that the 2.9 and $2.6 \mathrm{~kb}$ fragments were adjacent and also suggested that the $0.3 \mathrm{~kb} E c o \mathrm{RI}$ fragment is contiguous since the $P$ st I site at one end of the $1.6 \mathrm{~kb}$ PstI fragment lies within this fragment. The restriction map of the chromosome to the left-hand side of the Tn917 insertion is therefore as shown in Fig. 3.

\section{Demonstration that ger-97 is adjacent to rrnI}

Surprisingly, when the $9.0 \mathrm{~kb}$ fragment of pBMD1 was used as a hybridization probe it hybridized to a range of chromosomal EcoRI fragments, including one of $2.9 \mathrm{~kb}$, suggesting that the fragment carried a sequence that was repeated in the chromosome. The estimated sizes of these $E c o$ RI fragments $(9 \cdot 6,4 \cdot 1,3 \cdot 7,2 \cdot 9,1 \cdot 9,1 \cdot 6$ and $1 \cdot 3 \mathrm{~kb})$ showed close agreement with the sizes of chromosomal $E c o$ RI fragments which hybridize to 16 S ribosomal RNA $(10,4 \cdot 0,3 \cdot 5,3 \cdot 0$, $2 \cdot 0,1 \cdot 8,1.5$ and $0.8 \mathrm{~kb}$; Bott et al., 1981). This suggested that $\mathrm{Tn} 917$ had inserted into a DNA fragment which contained part of a 16 S RNA gene.

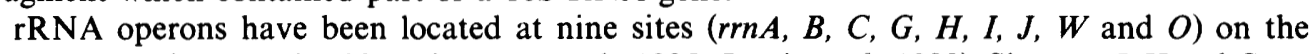
chromosome (Bott et al., 1984; Piggot \& Hoch, 1985; Jarvis et al., 1988). Since $r r n I, H$ and $G$ are located adjacent to each other in the region of gerD (Fig. 3; Jarvis et al., 1988) it seemed likely that ger-97:: Tn917 was located close to the $16 \mathrm{~S}$ end of one of these operons. To determine whether this was the case, use was made of the fact that a chromosomal restriction fragment would increase in size when $\mathrm{Tn} 917$ inserted into it, provided $\mathrm{Tn} 917$ itself did not carry a cleavage site for the enzyme. Phage $\lambda$ P13 (Bott et al., 1984) carries part of $r r n G$ (Fig. 3). The $4.6 \mathrm{~kb} E c o$ RI fragment of this phage, which contains a $B g I I$ site, was used to probe chromosomal DNA from the wild-type and from 5277, the strain in which pTV21 $\Delta 2$ had integrated into ger-97::Tn917, as this carried approximately $10 \mathrm{~kb}$ of integrated DNA with no $B g / \mathrm{II}$ sites. The probe was expected to hybridize to two chromosomal $B g I I I$ fragments. Since there are no $B g l I I$ sites within $r r n G, H$ or $I$, and none between the site of $\operatorname{Tn} 917$ insertion and the $16 \mathrm{~S}$ end of whichever operon lies close to it, then if this is $r r n I, H$ or $G$ one of the hybridizing fragments from strain 5277 should increase in size. As predicted, the $4.6 \mathrm{~kb}$ probe hybridized to two chromosomal Bg/II fragments of approximately 20 and $25 \mathrm{~kb}$. The $20 \mathrm{~kb}$ fragment increased in size to about $30 \mathrm{~kb}$ when DNA was inserted at the site of the ger-97::Tn917 mutation in strain 5277. This suggests that ger-97:: Tn917 does lie within or to the left of the $4.6 \mathrm{~kb}$ EcoRI fragment in Fig. 3.

When the $2.4 \mathrm{~kb} E c o \mathrm{RI}$ fragment from phage $\lambda \mathrm{P} 13$ was used to probe $B g / \mathrm{II}$-digested chromosomal DNA, hybridization occurred to the larger, $25 \mathrm{~kb}$ fragment to which the $4.6 \mathrm{~kb}$ probe had hybridized in wild-type DNA and this fragment did not increase in size in strain 5277. This further indicates that ger-97::Tn917 is to the left of the $4.6 \mathrm{~kb}$ EcoRI fragment and not to the right.

It seemed most likely that Tn917 had inserted near to the $16 \mathrm{~S}$ end of $r r n I$ (Fig. 3). The alternative possibilities, insertion between $r r n I$ and $r r n H$ or between $r r n H$ and $r r n G$, were excluded because DNA cloned from the left-hand side of the insertion, using pTV21 $\triangle 2$, would then also have been expected to have included sequences of rRNA genes repeated in other regions of the chromosome and therefore to be able to hybridize to a range of EcoRI fragments, as did the $9.0 \mathrm{~kb}$ fragment of $\mathrm{pBMDl}$. 

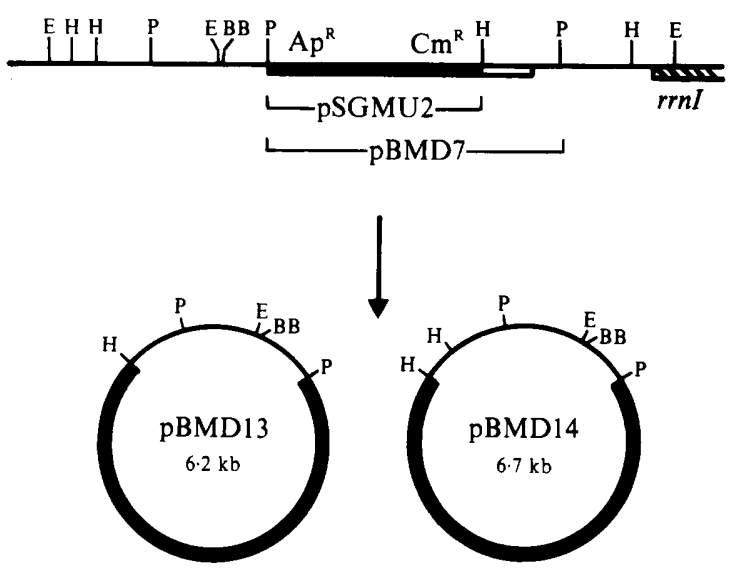

Fig. 4. Construction of pBMD13 and pBMD14. The wide solid lines represent pSGMU2 DNA, the open box Tn917 DNA. The restriction map shows 1604 DNA into which pBMD7 has integrated. Restriction sites are abbreviated as in Fig. 3. The chromosomal DNA was partially digested with $H$ indIII, fragments below $5.5 \mathrm{~kb}$ removed and the remainder ligated and used to transform $E$. coli, selecting Amp ${ }^{\mathrm{R}}$.

\section{Cloning the ger-97 region of the $B$. subtilis chromosome}

The $1.5 \mathrm{~kb}$ HindIII-Pst I fragment of pBMD1 and the $1.1 \mathrm{~kb}$ BamHI-PstI fragment of pBMD12 (Fig. 3) were cloned into pSGMU2 (Fort \& Errington, 1985) to give plasmids pBMD7 and pBMD10 respectively (Fig. 3). To determine whether these fragments were internal to the ger-97 transcriptional unit, plasmid DNA was used to transform strain 1604 to chloramphenicol resistance and the germination phenotype of transformants tested by the tetrazolium overlay method. A Cam ${ }^{\mathrm{R}} \mathrm{Ger}^{+}$strain and the ger-97::pTV21 12 strain, 5227, were used as $\mathrm{Ger}^{+}$and $\mathrm{Ger}^{-}$controls respectively. Transformants from both the pBMD7 $\times 1604$ and pBMD10 $\times 1604$ crosses were tzm-red, suggesting that both ends of the ger-97 transcriptional unit were present within the $1.8 \mathrm{~kb}$ Pst I fragment into which Tn917 had inserted (Fig. 3). Chromosomal DNA was prepared from a transformant of the cross pBMD7 $\times 1604$ which was presumed to contain pBMD7 integrated as shown in Fig. 4. The DNA was partially digested with HindIII and sizefractionated to remove fragments smaller than $5.5 \mathrm{~kb}$, in case integration of pBMD7 had resulted in tandem duplications of the $5.2 \mathrm{~kb}$ plasmid. Fragments over $5.5 \mathrm{~kb}$ were ligated and used to transform $E$. coli strain TB1 to ampicillin resistance. Three transformants were obtained which carried plasmids with an intact copy of the $1.8 \mathrm{~kb}$ Pst I fragment (Fig. 4). Two plasmids carried DNA to the next left-hand chromosomal HindIII site (pBMD13) and one also carried the HindIII fragment after that, an additional $0.5 \mathrm{~kb}$ (pBMD14). Circular DNA of pBMD13 and pBMD14 was used to transform strain 5215 to chloramphenicol resistance. Since circular DNA was used the plasmids would have integrated by Campbell recombination, resulting in a tandem duplication of the cloned DNA. One hundred transformants were allowed to sporulate on $\mathrm{NA}+$ chloramphenicol and tested for their germination phenotype by the tetrazolium test (with the controls as described above): all were red. Spores were prepared from one transformant from each cross and tested for their ability to germinate in Ala and AGFK. They germinated as well as strain 1604, suggesting that the cloned DNA was capable of complementing the ger-97:: Tn917 mutation.

The Pst Iragment from pBDM13 was subcloned into pSGMU2, forming pBMD18, and circular DNA of this plasmid was used to transform strains 5215, 5183 and 4738 to chloramphenicol resistance. In each case all of the 100 transformants tested were tzm-red and spores from representatives of each germinated as well as those of the wild-type strain. Thus the $1.8 \mathrm{~kb} P$ ' $t \mathrm{I}$ fragment was able to complement ger-97:: Tn917, gerD25 and gerD48 mutations, suggesting that it carried an intact ger $D$ gene or genes. Conversely, pBMD7 and pBMD10 were not able to complement any of the ger mutations. 


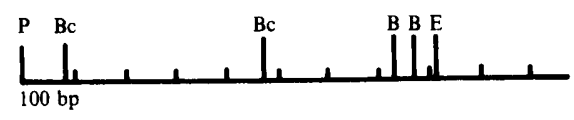

$(a)$

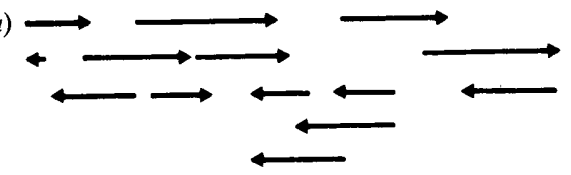

(b)

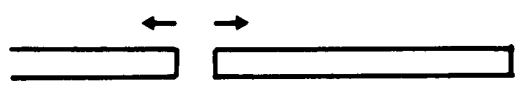

Fig. 5. (a) Strategy for sequencing the region of the $1.8 \mathrm{~kb}$ Pst I fragment where $T \mathrm{n} 917$ had inserted. Arrows indicate the starting points and extent of sequence determined from each clone. $(b)$ ORFs preceded by ribosome-binding sites. P, PstI; Bc, BclI; B, BamHI; E, EcoRI.

The $1.8 \mathrm{~kb}$ PstI fragment from pBMD13 was also subcloned in both orientations in plasmid pMK4, which is able to replicate in $B$. subtilis, forming plasmids pBMD16 and pBMD17. RecEstrains 5226 and 5227 (constructed as shown in Table 1) were transformed with pBMD16 and pBMD17 and compared by the tetrazolium overlay test with the parental strains and strain 4930, each carrying pMK4. The transformant colonies from all the crosses were pink as compared with the red colonies of 4930 (pMK4) or white colonies of 5226(pMK4) or 5227(pMK4), suggesting that complementation of the ger mutations was not perfect. This was confirmed by the rates of germination of spores of the transformant colonies, which were intermediate between those of the $\mathrm{Ger}^{+}$and $\mathrm{Ger}^{-}$controls. One explanation for this result could be that multiple copies of gerD or some other sequence on the $1.8 \mathrm{~kb}$ fragment are suboptimal for germination.

\section{Cloning the ger-97 region in a $\lambda$ vector}

The approximately $20 \mathrm{~kb} \mathrm{Bg} / \mathrm{II}$ fragment carrying ger-97 was within the cloning capacity of $\lambda E M B L 3$ (Frischauf et al., 1983). A $\lambda$ EMBL3 bank of strain 1604 DNA was constructed and screened for phage carrying DNA homologous to the ger-97 region as described in Methods. Restriction enzyme analysis and hybridization studies showed that the DNA from one of nine phages $(22 \mathrm{H})$ which gave positive hybridization signals came from the ger-97 region. The cloned DNAs from the remaining eight phages had restriction maps consistent with their having been derived from the region of $r r n B$ (Bott et al., 1984; not shown). Phage $\lambda 2 \mathrm{H}$ appeared from hybridization studies and its restriction map to contain DNA from the $16 \mathrm{~S}$ end of $r r I$ and the $5 \mathrm{~S}$ end of $r r G G$ but the intervening $r r n$ operons and intervening sequences had been deleted (Fig. 3). A possible explanation for this is that the phage was isolated in a recombination-proficient host which would have permitted homologous recombination to take place between $r r n I$ and $r r n G$ with the deletion of the equivalent of two rrn operons. The restriction map of the cloned DNA in $\lambda 2 \mathrm{H}$ was identical, in the region to the left of the $16 \mathrm{~S}$ end of $r r n I$ (Fig. 3), to that obtained from the clones derived using pTV20 and pTV21 2 , confirming the restriction map of this region.

\section{DNA nucleotide sequence of the $1.8 \mathrm{~kb}$ Pst fragment}

The $1.8 \mathrm{~kb}$ Pst I fragment of $\lambda 2 \mathrm{H}$ was cloned into $\mathrm{M} 13 \mathrm{mp} 19$ and sequenced as described in Methods. Fig. 5 shows the extent of the sequences derived from clones in the region of the $\operatorname{Tn} 917$ insertion. In this region an open reading frame (ORF) starting with an ATG codon and preceded by a sequence (GAAAGGAG) complementary to the $3^{\prime}$ end of $B$. subtilis $16 \mathrm{~S}$ rRNA was identified starting at position 381 of the sequence shown in Fig. 6 and terminating at an ochre codon (TAA) at position 936. This reading frame spans the EcoRI site and the site of Tn917 insertion situated approximately $300 \mathrm{bp}$ upstream and codes for a polypeptide of 
CTGCAGCAAATTCCACAAAGAGGAGGACCTTAATATCTCAAGCGCAAACCGATGAACTGTTAAAAACACGAAAAAACCCATTTGGCTGATCACACTGAAA GACGTCGTTTAAGGTGTTTCTCCTCCTGGAATTATAGAGTTCGCGTTTGGCTACTTGACAATTTTTGTGCTTTTTTGGGTAAACCGACTAGTGTGACTTT Pst I

ATCATGCCTACACCGATAAACCAAAATAAAACAGAGAAAATCTGTCCCGCTTCAAATGTTAGAAACAGCCCTCTATATTCTCCCCACTTTAAAGCAAAAC TAGTACGGATGTGGCTATTTGGTTTTATTTTGTCTCTTTIAGACAGGGCGAAGTTTACAATCTTTGTCGGGAGATATAAGAGGGGTGAAATTTCGTTTTG

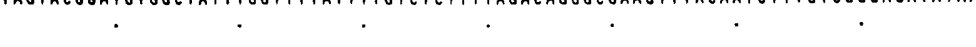

CCACAATACTCGTGATAAGCGCCCCGACAGCTAAAATAGAAAAGAAAAAACGAACTAAACCACGGCTTTTCATTTCTTTATTCATCCCCTCAAAAAUCGC GGTGTTATGAGCACTATTCGCGGGGCTGTCGATTTTATCTTITCTTTTTTGCTTGATTTGGTGCGGAAAAGTAAAGAAATAAGTAGGGGAGTTTTTAGCG

$\longrightarrow S \quad K \quad A \quad K \quad T \quad L$

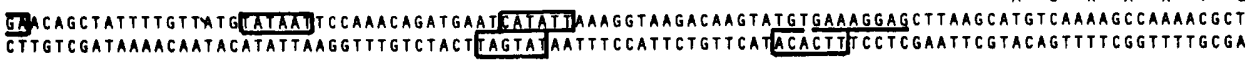

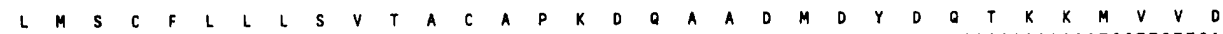
ATIGATGAGCTGTTTTTTGTTATTATCTGTAACAGCTTGCGCTCCAAAAGACCAAGCAGCGGATATGGACTATGATCAGACCAAAAAAATGGTTGTTGAT TAACTACTCGACAAAAAACAATAATAGACATTGTCGAACGCGAGGTTTCTGGTTCGTCGCCTATACCTGATACTAGTCTGGTTTTTTTACCAACAACTA

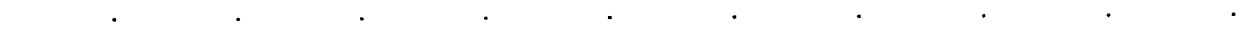

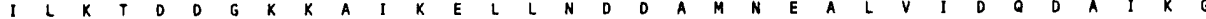
ATATTAAAAACTGATGATGGAAAGAAAGCTATTAAGGAATTATTAAATGATGATGCCATGAATGAAGCGCTGGTGATTGACCAAGATGCAATTAAAGGAA TATAATITTTGACTACTACCTTTCTTICGATAATTCCTTAATAATTTACTACTACGGTACTTACTTCGCGACCACTAACTGGTTCTACG TTAATTTCCTT

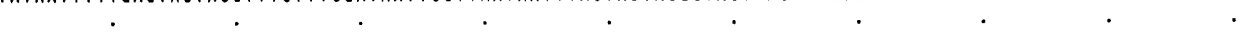

$$
\text { BamHI } \cdot \cdot \cdot \cdot B a m H I
$$

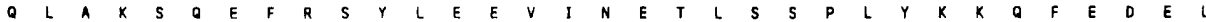
CAGCTGGCAAAAAGCCAAGAATTCCGCAGTTATITAGAAGAGGTTATTAACGAAACACTTTCTAGTCCGCTTTACAAAAAGCAGTTCGAAGATGAGCTGA GTCGACCGTTTTTCGGTICTIAAGGCGICAATAAATCTTCTCCAATAATTGCTTTGTGAAAGATCAGGCGAAATGTITTTCGTCAAGCTTCTACTCGACT

\section{EcoRI}

K K A A K D T A K E S E FW

AAAAAGCAGCAAAAGACACAGCAAAAGAAAGTGAATAAAGGGAAAGCCGGGATCTGGAATCCCGGTTCACCTTTTATACCTGCACTGACATTTTTGCATC FITTTCGTCGTTTTCTGTGTCGTTTCTTTCACTTATTTCCCTTTCGGCCCTAGACCTTAGGGCCAATGGAAAATATGGACGTACTGTAAAAACGTAG

TATTTTTTTTGCGATgTCCTGATATATTTCTCCGATTGGATGATTTTCGTATA ATAAAAAAAACGCTACAGGACTATATAAAGAGgCTAACCTACTAAAAGCATAT

Fig. 6. DNA nucleotide sequence of the region of the Tn 917 insertion in the $1.8 \mathrm{~kb}$ fragment, showing the amino acid sequence of the proposed ger-97 polypeptide, potential promoter and terminator regions and ribosome-binding sites. Potential ribosome-binding sites are underlined and potential promoter regions shown by boxes. The stop codon is marked with asterisks and a region of dyad symmetry shown by divergent arrows.

predicted molecular mass $21117 \mathrm{Da}$. The mRNA from positions $947-965$ in the DNA sequence could form part of a transcription terminator structure. Upstream of the putative gerD ORF is a consensus $\sigma^{\mathrm{E}}$ ' -10 ' region, CATATT, starting at position 341 (Fig. 6) but the ' -35 ' region, TATAA, is not a perfect match to the $\sigma^{\mathrm{E}}$ consensus of TTNAA (Cowing et al., 1985). There is a 


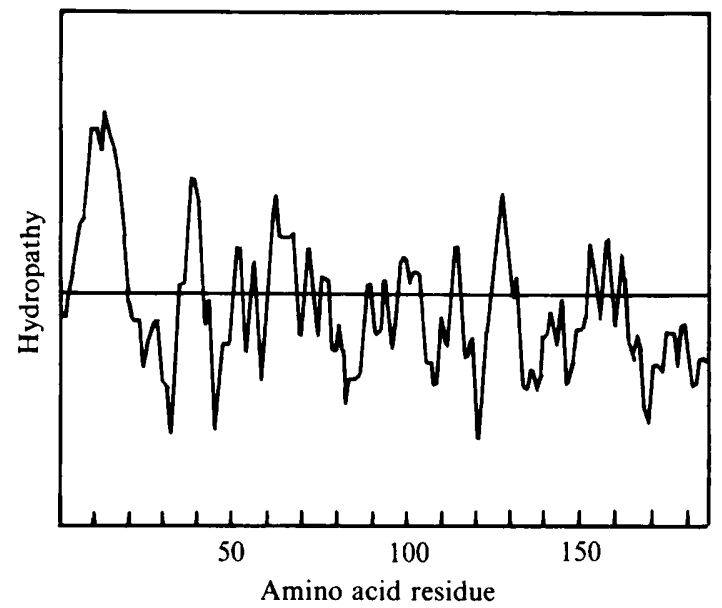

Fig. 7. Hydroplot of the ger-97 polypeptide. The average hydropathy value of a seven-amino-acid window centred on each residue along the sequence is plotted. Hydrophobic regions have a high average hydropathy. The top of the figure represents the value of the most hydrophobic residue, the bottom that of the most hydrophilic. The horizontal line represents the average hydropathy of a large number of sequenced proteins (Kyte \& Doolittle, 1982).

second possible promoter region with TATAAT at ' -10 ' (starting position 320 ) which is a perfect consensus for $\sigma^{\mathrm{A}}$ but the sequence at " -35 ' is TCGCGA, which is a poor match for the consensus TTGAca (Cowing et al., 1985). A second ORF preceded by a ribosome-binding site begins upstream of the putative ger-97 ORF leading from the other strand in the opposite direction. It is preceded by possible promoter regions indicated in Fig. 6.

A 'hydroplot' (Kyte \& Doolittle, 1982; Fig. 7) of the proposed gerD polypeptide showed that the bulk of the protein is hydrophilic, but there is a hydrophobic amino terminal region 14-16 amino acids long, preceded by four hydrophilic amino acids, which resembles a signal sequence. The most likely position for a cleavage site in the ger-97 polypeptide is between the two adjacent alanine residues at positions 26 and 27 (scoring 15 on the 'processing probability' scale of Von Heijne, 1983). The factors which make this the most likely site are the proline residue at position -5 and the alanine at position -1 from the cleavage site. The glutamate residue at position -3 is however highly unfavourable and would argue against this being the cleavage site. A second possible position is after the alanine residue at position 21 (scoring 13.1). This is marked down because of the proline residue at position +1 which would be most unusual, although it is not certain whether a proline residue in this position would actually prevent cleavage at this site in vivo (Von Heijne, 1983).

\section{DISCUSSION}

The sequence of markers shown in Fig. 2 is the most likely order consistent with the mapping and hybridization data described here. Confirmation of the location of $\operatorname{ger} D$ adjacent to $r r n I$ has been obtained from sequencing data of $\mathrm{K}$. Bott (unpublished). Work of Jarvis et al. (1988) confirms the relative order of cysA rpsE and $r r n I$ and also shows that the attachment site for SPO2 maps between rpsE and rrnI. Irie et al. (1982) mapped attSPO2 between $c y s A$ and gerD, so that the relative order of markers in this region is likely to be cysA rpsE (rpsI attSPO2) gerD rrnI. The relative order of $r p s I$ and attSPO2 remains uncertain. $r p s I$ is $3-4 \mathrm{~kb}$ from gerD (according to the formula of Kemper, 1974, and the transformation data in Table 2) and could be present on $22 \mathrm{H}$. Further characterization of this and other clones from the region which carry attSPO2 (K. Bott, unpublished) should establish the relative order of markers.

The proximity of ger-97 to the $16 \mathrm{~S}$ end of $r r n I$ could explain the failure to isolate plasmids consisting solely of the $9 \mathrm{~kb}$ fragment of $\mathrm{pBMD} 1$ and $\mathrm{pBMD} 2$, as the rrnI promoter would be 
located near one end of this EcoRI fragment. Circularization of this fragment would give transcription into the $\beta$-lactamase gene and plasmid replication functions of pTV20 and might prevent maintenance of the plasmid. This would accord with the observation of Bott et al. (1984) that $B$. subtilis rRNA operon promoters cause plasmid instability when maintained in $E$. coli on plasmids which do not contain transcription termination signals. Presumably such signals are present in the extra EcoRI fragments of pBMD1 and pBMD2.

The complementation studies show that ger $D$ is present on the $1.8 \mathrm{~kb}$ Pst $\mathrm{I}$ fragment cloned in pSGMU2; and the observation that pBMD7 and pBMD10, which carry DNA that does not span the site of Tn917 insertion and includes only part of the ger-97 ORF identified in the DNA sequence of this region, are unable to complement ger $D$ mutations strongly suggests that the ger-97 ORF is that of gerD. The identity of the ORF upstream of the proposed ger $D$ ORF, which is preceded by a ribosome-binding site and a promoter region reading in the opposite direction to the $\operatorname{ger} D$ ORF, is unknown. Downstream of $\operatorname{ger} D$ none of the potential ORFs observed were preceded by ribosome-binding sites. The phenotype of the ger-97:: $\operatorname{Tn} 917$ mutant very closely resembled that of the ger $D 25$ and gerD 48 mutants except that the ger-97::Tn 917 mutant spores did not germinate better in Ala when $\mathrm{KCl}$ was added. This would be explained if insertion of Tn917 into the gerD gene completely abolishes its function. Mutants gerD25 and gerD48 probably result from point mutations which might lead to mutant gene products that could operate better in an environment of high ionic strength.

The function of ger $D$ is unknown, and computer-assisted protein sequence homology searches have not revealed homology between the ger $D$ polypeptide and other sequences. The location of ger $D$ between clusters of ribosomal protein and ribosomal RNA genes is particularly intriguing and suggests that ger $D$ may have a role in translation. However, there is as yet no evidence to support this. Irie et al. (1985) suggested that the gerD product may be involved in fructose recognition during germination since with ger $D$ mutant spores addition of fructose does not alleviate the inhibitory effect of D-alanine on L-alanine-stimulated germination, whereas it does with wild-type spores. Vegetative cells of gerD25 and the ger-97:: Tn 917 mutant are able to grow at the same rate as wild-type cells when using fructose as a source of carbon (R. Sammons, unpublished). Nevertheless recognition of fructose may be impaired in ger $D$ spores. Cloning and knowledge of the gerD sequence will now permit in vitro mutagenesis, which will aid investigation of this and other aspects of the ger $D$ phenotype. It should also be possible to obtain the ger $D$ gene product in vitro for further study. The possibility that multiple copies of ger $D$ may be suboptimal or inhibitory to germination also merits investigation. One possible clue to the function of $\operatorname{ger} D$ is the presence of a signal sequence at the $\mathrm{N}$-terminus of the polypeptide, which suggests that it is transported through a membrane. Whether the gerD product is made in the mother cell and transported into the forespore, or vice versa, is at present unknown. Preliminary studies in which gerD gene has been fused to lac $Z$ (R. Sammons, unpublished) suggest that gerD is active between $t_{2}$ and $t_{6}$ of sporulation. Studies to confirm this, and further experiments on ger $D$ expression in different spo and ger mutant backgrounds, are in progress.

We thank Drs Ken Bott, Jeff Errington, Anne Moir, Chris Smith and Chris Franklin for gifts of phage and plasmids and for much helpful discussion. We are also grateful to Joyce Yeomans, Hazel Howell, Marian Saunders and Marian Coley for technical help. Especial thanks are given to Liz Badger and Shirley Hackett for excellent secretarial assistance. This work was supported by the Science and Engineering Research Council.

\section{REFERENCES}

Benton, W. D. \& Davis, R. W. (1977). Screening $\lambda$ t recombinant clones by hybridisation to single plaques in situ. Science 196, 180-182.

Biggin, M. D., Gibson, T. J. \& Hong, G. F. (1983). Buffer gradient gels and $35 S$ label as an aid to rapid DNA sequence determination. Proceedings of the National Academy of Sciences of the United States of America 80, 3963-3965.
Bott, K. F., Wilson, F. E. \& Stewart, G. C. (1981). Characterisation of Bacillus subtilis rRNA genes. In Sporulation and Germination, pp. 119-122. Edited by H. S. Levinson, A. L. Sonenshein \& D. J. Tipper. Washington, DC: American Society for Microbiology.

Bott, K. F., Stewart, G. C. \& Anderson, A. G. (1984). Genetic mapping of cloned ribosomal RNA 
genes. In Genetics and Biotechnology of Bacilli, pp. 19-34. Edited by A. T. Ganesan \& J. A. Hoch. New York: Academic Press.

Cowing, D. W., Bardwell, J. C. A., Craig, E. A., WoOlford, C., Hendrix, R. W. \& Grass, C. A. (1985). Consensus sequence for Escherichia coli heat shock gene promoters. Proceedings of the National Academy of Sciences of the United States of America 82, 2679-2683.

CUTTING, S. \& Mandelstam, J. (1986). The nucleotide sequence and the transcription during sporulation of the gerE gene of Bacillus subtilis. Journal of General Microbiology 132, 3013-3024.

DABBS, E. R. (1983). Mapping of the genes for Bacillus subtilis ribosomal proteins S9, S11 and BL27 by means of antibiotic resistant mutants. Molecular and General Genetics 191, 295-300.

DrING, G. J. \& GouLD, G. W. (1971). Movement of potassium during L-alanine initiated germination of Bacillus subtilis spores. In Spore Research, pp. 133141. Edited by A. N. Barker, G. W. Gould \& J. Wolf. London: Academic Press.

FORT, P. \& ERrington, J. (1985). Nucleotide sequence and complementation analysis of a polycistronic sporulation operon, spoVA, in Bacillus subtilis. Journal of General Microbiology 131, 10911105.

Frischauf, A., Lehrach, H., Poustra, A. \& Murray, N. E. (1983). Lambda replacement vectors carrying polylinker sequences. Journal of Molecular Biology 170, 827-842.

Hasnain, S., Sammons, R., Roberts, I. \& Thomas, C. M. (1985). Cloning and deletion analysis of a genomic segment of Bacillus subtilis coding for the $s d h A, B, C$ (succinate dehydrogenase) and gerE (spore germination) loci. Journal of General Microbiology 131, 2269-2279.

HENIKOFF, S. (1984). Unidirectional digestion with exonuclease III creates targeted breakpoints for DNA sequencing. Gene 28, 351-359.

Henkin, T. M. \& Chambliss, G. H. (1984). Genetic analysis of a streptomycin resistant oligosporogenous Bacillus subtilis mutant. Journal of Bacteriology 157, 202-210.

Holland, S. K., Cutting, S. \& Mandelstam, J. (1987). The possible DNA-binding nature of the regulatory proteins, encoded by spoIID and gerE, involved in the sporulation of Bacillus subtilis. Journal of General Microbiology 133, 2381-2391.

Irie, R., Okamoto, T. \& Fujita, Y. (1982). A germination mutant of Bacillus subtilis deficient in response to glucose. Journal of General and Applied Microbiology 28, 345-354.

IrIE, R., OKaMoto, T. \& FuJITA, Y. (1985). Characterisation and mapping of Bacillus subtilis ger D mutants. Journal of General and Applied Microbiology 32, 303315.

James, W. S. \& Mandelstam, J. (1985). Protease production during sporulation of germination mutants of Bacillus subtilis and the cloning of a functional gerE gene. Journal of General Microbiology 131, 2421-2430

Jarvis, E. D., Widom, R. L., La Fauci, G., SetoGUCHI, Y., RICHTER, I. R. \& RUDNER, R. L. (1988). Chromosomal organisation of rRNA operons in Bacillus subtilis. Genetics 120, 625-635.
Jenkinson, H. F. \& LoRD, H. (1983). Protease deficiency and its association with defects in spore coat structure, germination and resistance properties in a mutant of Bacillus subtilis. Journal of General Microbiology 129, 2727-2737.

Karn, J., Brenner, S., Barnett, L. \& Cesareni, G. (1980). Novel bacteriophage cloning vector. Proceedings of the National Academy of Sciences of the United States of America 77, 5172-5176.

KEMPER, J. (1974). Gene order and co-transduction in the leu ara fol pyrA region of the Salmonella typhimurium linkage map. Journal of Bacteriology 117, 94-99.

Kyte, J. \& Doolittle, R. F. (1982). A simple method for displaying the hydropathic character of a protein. Journl of Molecular Biology 157, 105-132.

LAFFERTY, E. \& MoIR, A. (1977). Further studies on conditional germination mutants of Bacillus subtilis 168. In Spore Research 1976, pp. 87-105. Edited by A. N. Barker, J. Wolf, D. J. Ellar, G. J. Dring \& G. W. Gould. London: Academic Press.

Maniatis, T., Fritsch, E. F. \& SAMbroOK, J. (1982). Molecular Cloning. A Laboratory Manual. Cold Spring Harbor, NY: Cold Spring Harbor Laboratory.

Messing, J. (1983). New M13 vectors for cloning. Methods in Enzymology 101, 20-78.

MiLleR, J. (1972). Experiments in Molecular Genetics. Cold Spring Harbor, NY: Cold Spring Harbor Laboratory.

MolR, A. (1983). The isolation of $\lambda$ transducing phages carrying the cit $G$ and ger $A$ genes of Bacillus subtilis. Journal of General Microbiology 129, 303-310.

MoIR, A., LafFerTy, E. \& SMITH, D. A. (1979). Genetic analysis of spore germination mutants of Bacillus subtilis 168: the correlation of phenotype with map locations. Journal of General Microbiology 111, 165-180.

Moir, A., Feavers, I. M., Zuberi, A. R., Sammons, R. L., Roberts, I. S., YoN, J. R., WolfF, E. A. \& SMITH, D. A. (1985). Progress in the molecular genetics of spore germination in Bacillus subtilis 168 . In Molecular Biology of Microbial Differentiation, pp. 35-46. Edited by J. A. Hoch \& P. Setlow. Washington DC: American Society for Microbiology.

Murray, N. E., Mandura DE RITIS, P. \& Foster, L. A. (1973). DNA targets for the Escherichia coli K restriction system analysed genetically in recombinants between phages phi80 and lambda. Molecular and General Genetics 120, 261-281.

PIgGot, P. J. \& Hoch, J. A. (1985). Revised genetic linkage map of Bacillus subtilis. Microbiological Reviews 49, 158-179.

Piggot, P. J., MoIR, A. \& SMITH, D. A. (1981). Advances in the genetics of Bacillus subtilis differentiation. In Sporulation and Germination, pp. 29-39. Edited by H. S. Levinson, A. L. Sonenshein \& D. J. Tipper. Washington, DC: American Society for Microbiology.

Prasad, C., Diesterhaft, M. \& Freese, E. (1972). Initiation of spore germination in glycolytic mutants of Bacillus subtilis. Journal of Bacteriology 110, 321328.

ROBERTS, I. R. (1983). The cloning of Bacillus subtilis $D N A$-proximal to the gerE and gerF germination genes. PhD thesis, University of Birmingham, UK. 
Sammons, R. L. \& Anagnostopoulos, C. (1982). Identification of a cloned DNA segment at a junction of chromosomal regions involved in rearrangements in the trpE26 strains of Bacillus subtilis. FEMS Microbiology Letters 15, 265-268.

Sammons, R. L., MoIR, A. \& Smith, D. A. (1981). Isolation and properties of spore germination $\mathrm{mu}-$ tants of Bacillus subtilis 168 deficient in the initiation of germination. Journal of General Microbiology 124, 229-241.

Sammons, R. L., SlynN, G. M. \& SMith, D. A. (1987). Genetical and molecular studies on ger $M$, a new developmental locus of Bacillus subtilis. Journal of General Microbiology 133, 3299-3312.

SANGer, F., Nicklen, S. \& Coulson, A. R. (1977). DNA sequencing with chain terminating inhibitors. Proceedings of the National Academy of Sciences of the United States of America 74, 5463-5467.

Sullivan M. A., Yasbin, R. E. \& Young, F. E. (1984). New shuttle vectors of Bacillus subtilis and Escherichia coli which allow rapid detection of inserted fragments. Gene 29, 21-26.

Trowsdale, J. \& SMITH, D. A. (1975). Isolation, characterisation and mapping of Bacillus subtilis 168 germination mutants. Journal of Bacteriology 123, 83-95.

Von Heijne, G. (1983). Patterns of amino acids near signal sequence cleavage sites. European Journal of Biochemistry 133, 17-21.

WARBURG, R. J. (1981). Some pleiotropic mutations affecting spore germination in Bacillus subtilis 168 . $\mathrm{PhD}$ thesis, University of Birmingham, UK.

Warburg, R. J., MoIr, A. \& SMITH, D. A. (1985). Influence of alkali metal cations on the germination of spores of wild-type and gerD mutants of Bacillus subtilis. Journal of General Microbiology 131, 221230.

Warburg, R. J., Buchanan, C. E., Parent, K. \& Halvorson, H. O. (1986). A detailed study of gerJ mutants of Bacillus subtilis. Journal of General Microbiology 132, 2309-2319.

Wilkinson, B. J., EllaR, D. J., ScotT, I. R. \& KoNCEWITZ, M. A. (1977). Rapid chloramphenicolresistant activation of membrane electron transport on germination of Bacillus spores. Nature, London 266, 174-176.

YANISCh-PERRon, C., Vieira, J. \& Messing, J. (1985). Improved M13 phage cloning vectors and host strains: nucleotide sequences of the $\mathrm{M} 13 \mathrm{mpl} 8$ and pUC19 vectors. Gene 33, 103-119.

YAZDI, M. (1989). Genetic and molecular analysis of the gerC spore germination locus of Bacillus subtilis 168. PhD thesis, University of Sheffield, UK.

Youngman, P. J., Perkins, J. B. \& Losick, R. (1983). Genetic transposition and insertional mutagenesis in Bacillus subtilis with the Streptococcus faecalis transposon Tn917. Proceedings of the National Academy of Sciences of the United States of America 80, 23052309.

Youngman, P. J., Perkins, J. B. \& Losick, R. (1984). A novel method for the rapid cloning in Escherichia coli of Bacillus subtilis DNA adjacent to Tn917 insertions. Molecular and General Genetics 195, 424 433.

Zuberi, A. R., Feavers, I. M. \& Molr, A. (1985). Identification of three complementation units in the gerA spore germination locus of Bacillus subtilis. Journal of Bacteriology 162, 756-762. 